2012

\title{
A Shell-Neutral Modeling Approach Yields Sustainable Oyster Harvest Estimates: A Retrospective Analysis of the Louisiana State Primary Seed Grounds
}

Thomas M. Soniat

John M. Klinck

Old Dominion University, jklinck@odu.edu

Eric N. Powell

Nathan Cooper

Mahdi Abdelguerfi

See next page for additional authors

Follow this and additional works at: https://digitalcommons.odu.edu/ccpo_pubs

Part of the Oceanography and Atmospheric Sciences and Meteorology Commons

\section{Repository Citation}

Soniat, Thomas M.; Klinck, John M.; Powell, Eric N.; Cooper, Nathan; Abdelguerfi, Mahdi; Hofmann, Eileen E.; Dahal, Janak; Tu, Shengru; Finigan, John; Eberline, Benjamin S.; La Peyre, Jerome F.; La Peyre, Megan K.; and Qaddoura, Fareed, "A Shell-Neutral Modeling Approach Yields Sustainable Oyster Harvest Estimates: A Retrospective Analysis of the Louisiana State Primary Seed Grounds" (2012). CCPO Publications. 12.

https://digitalcommons.odu.edu/ccpo_pubs/12

\section{Original Publication Citation}

Soniat, T.M., Klinck, J.M., Powell, E.N., Cooper, N., Abdelguerfi, M., Hofmann, E.E., ... Qaddoura, F. (2012). A shell-neutral modeling approach yields sustainable oyster harvest estimates: A retrospective analysis of the Louisiana state primary seed grounds. Journal of Shellfish Research, 31(4), 1103-1112. doi: 10.2983/035.031.0421 


\section{Authors}

Thomas M. Soniat, John M. Klinck, Eric N. Powell, Nathan Cooper, Mahdi Abdelguerfi, Eileen E. Hofmann, Janak Dahal, Shengru Tu, John Finigan, Benjamin S. Eberline, Jerome F. La Peyre, Megan K. La Peyre, and Fareed Qaddoura 


\section{A Shell-Neutral Modeling Approach Yields Sustainable Oyster Harvest Estimates: A Retrospective Analysis of the Louisiana State Primary Seed Grounds}

Author(s): Thomas M. Soniat, John M. Klinck, Eric N. Powell, Nathan Cooper, Mahdi Abdelguerfi, Eileen E. Hofmann, Janak Dahal, Shengru Tu, John Finigan, Benjamin S. Eberline, Jerome F. La Peyre, Megan K. La Peyre and Fareed Qaddoura

Source: Journal of Shellfish Research, 31(4):1103-1112.

Published By: National Shellfisheries Association

DOI: http://dx.doi.org/10.2983/035.031.0421

URL: http://www.bioone.org/doi/full/10.2983/035.031.0421

BioOne (www.bioone.org) is a nonprofit, online aggregation of core research in the biological, ecological, and environmental sciences. BioOne provides a sustainable online platform for over 170 journals and books published by nonprofit societies, associations, museums, institutions, and presses.

Your use of this PDF, the BioOne Web site, and all posted and associated content indicates your acceptance of BioOne's Terms of Use, available at www.bioone.org/page/terms_of_use.

Usage of BioOne content is strictly limited to personal, educational, and non-commercial use. Commercial inquiries or rights and permissions requests should be directed to the individual publisher as copyright holder. 


\title{
A SHELL-NEUTRAL MODELING APPROACH YIELDS SUSTAINABLE OYSTER HARVEST ESTIMATES: A RETROSPECTIVE ANALYSIS OF THE LOUISIANA STATE PRIMARY SEED GROUNDS
}

\author{
THOMAS M. SONIAT, ${ }^{1 *}$ JOHN M. KLINCK, ${ }^{2}$ ERIC N. POWELL,${ }^{3}$ NATHAN COOPER, ${ }^{4}$ \\ MAHDI ABDELGUERFI, ${ }^{4}$ EILEEN E. HOFMANN, ${ }^{3}$ JANAK DAHAL ${ }^{4}$ SHENGRU TU, ${ }^{4}$ \\ JOHN FINIGAN, ${ }^{4}$ BENJAMIN S. EBERLINE, ${ }^{5}$ JEROME F. LA PEYRE, ${ }^{6}$ MEGAN K. LA PEYRE ${ }^{5,7}$ \\ AND FAREED QADDOURA ${ }^{4}$ \\ ${ }^{1}$ Department of Biological Sciences and Pontchartrain Institute for Environmental Sciences, University of \\ New Orleans, 2000 Lakeshore Drive, New Orleans, LA 70148; ${ }^{2}$ Center for Coastal Physical Oceanography, \\ 4111 Monarch Way, $3^{\text {rd }}$ Floor, Old Dominion University, Norfolk, VA 23529; ${ }^{3}$ Haskin Shellfish Research \\ Lab, Rutgers University, 6959 Miller Avenue, Bivalve, NJ 08349; ${ }^{4}$ Department of Computer Science, \\ University of New Orleans, 2000 Lakeshore Drive, New Orleans, LA 70148; ${ }^{5}$ School of Renewable Natural \\ Resources, Louisiana State University Agricultural Center, 227 Renewable Natural Resources Bldg., Baton \\ Rouge, LA 70803; ${ }^{6}$ Cooperative Aquatic Animal Health Research Program, Department of Veterinary \\ Science, Louisiana State University Agricultural Center, 111 Dalrymple Bldg., LSU Campus, Baton Rouge, \\ LA 70803; ${ }^{7}$ U.S. Geological Survey, Louisiana Cooperative Fish and Wildlife Research Unit, 124 School of \\ Renewable Natural Resources, Louisiana State University Agricultural Center, Baton Rouge, LA 70803
}

\begin{abstract}
A numerical model is presented that defines a sustainability criterion as no net loss of shell, and calculates a sustainable harvest of seed $(<75 \mathrm{~mm})$ and sack or market oysters $(\geq 75 \mathrm{~mm})$. Stock assessments of the Primary State Seed Grounds conducted east of the Mississippi from 2009 to 2011 show a general trend toward decreasing abundance of sack and seed oysters. Retrospective simulations provide estimates of annual sustainable harvests. Comparisons of simulated sustainable harvests with actual harvests show a trend toward unsustainable harvests toward the end of the time series. Stock assessments combined with shell-neutral models can be used to estimate sustainable harvest and manage cultch through shell planting when actual harvest exceeds sustainable harvest. For exclusive restoration efforts (no fishing allowed), the model provides a metric for restoration success - namely, shell accretion. Oyster fisheries that remove shell versus reef restorations that promote shell accretion, although divergent in their goals, are convergent in their management; both require vigilant attention to shell budgets.
\end{abstract}

KEY WORDS: oyster, Crassostrea virginica, fisheries, modeling, stock assessment, restoration, sustainability, shell budget, Louisiana

\section{INTRODUCTION}

Copious flows of fresh water into the shallow subtropical waters of coastal Louisiana generate a broad mesohaline zone that supports abundant populations of eastern oysters, Crassostrea virginica (Chatry et al. 1983, Melancon et al. 1998). Louisiana typically leads the country in the production of oysters, accounting for about $34 \%$ of the nation's landings and more than $50 \%$ of the landings along the Gulf of Mexico, with a dockside value of about \$35 million per year (Dugas et al. 1997, LDWF 2010). The Louisiana Department of Wildlife and Fisheries (LDWF) is charged with the management of nearly 1.7 million acres of public water bottoms, wherein it sets seasons, monitors harvest, and plants cultch. The industry also includes a private sector to which the state leases about 385,000 acres of water bottom.

Long-term annual average harvest from the public grounds is about 3 million $\mathrm{lb}$. of meat, whereas private leases supply about 8 million lb. of meat per year (LDWF 2010).

The success of the Louisiana oyster industry is a result, in large part, of a public/private partnership in which the LDWF manages the public grounds for the production of seed oysters $(<75 \mathrm{~mm})$ for transplant to private leases, where they are cultivated and subsequently harvested. However, a significant increase in the harvest of market-size (or sack) oysters $(\geq 75 \mathrm{~mm}$ )

*Corresponding author. E-mail: tsoniat@uno.edu DOI: $10.2983 / 035.031 .0421$ has occurred from public grounds during the past $15 \mathrm{y}$. (Marketsize or sack oysters are harvested, sacked, and marketed directly whereas seed oysters are harvested, transplanted to private leases for grow-out, reharvested, and then marketed.) The quantity of shell being removed as seed, sack, and associated cultch far exceeds the quantity of cultch planted by the state, resulting in a potential net deficit of shell, and threatening the sustainability of the resource. Currently, annual stock assessments, combined with best professional judgment, are used both to inform management and to predict the success of the upcoming oyster season (e.g., LDWF 2010). Although these data provide crucial information for tracking oyster stock on an annual basis, current management has no established biological reference point and, consequently, no criterion by which sustainable harvest can be estimated.

Powell and Klinck (2007) developed 2 biological reference points for oysters: an abundance (or biomass) reference point and a substrate reference point, formalized respectively as

$$
\frac{d N}{d t}=0
$$

and

$$
\frac{d S}{d t}=0
$$

where $N$ is the abundance of oysters, $S$ is the quantity of surficial shell, and $t$ is time. Eq (1) requires that recruitment equal 
combined fishing and natural mortalities whereas Eq (2) requires that shell lost to fishing and natural processes equal shell gains. A goal for sustainable management might demand that harvest not exceed recruitment and, simultaneously, that shell loss not exceed natural and enhanced replenishment. A number of biological reference points have been put forward that define the value of $N$ in Eq (1) (Klinck et al. 2001, Powell et al. 2009a), but they do not necessarily establish an abundance consistent with Eq (2) (Powell et al. 2012). Arguably, the primary management and restoration goal is that expressed by Eq (2), the sustainability of substrate, rather than that expressed by Eq (1), the sustainability of abundance (Mann \& Powell 2007), as the former depends ineluctably on the latter and demands a robust population density (Powell et al. 2012). Moreover, the cost of restoring abundance, although expensive, is minimal in comparison with the cost of restoring habitat. Thus, habitat, and hence shell, conservation is an economically advantageous goal. To this end, management for no net shell loss seems especially appropriate for oysters along the northern Gulf of Mexico, which are characterized by vibrant populations, good recruitment, and large interannual variations in numbers (Ingle \& Dawson 1952, Butler 1953, Hopkins 1954, Hayes \& Menzel 1981, Choi et al. 1994).

A numerical model for the sustainable management of oysters in Louisiana, which emphasizes the primacy of managing for no net shell loss over management for constant abundance, is presented. Annual stock assessments of oyster density and size are inputs into the model to estimate retrospectively the number of sacks of seed and market-size (sack) oysters that are harvestable with no net loss of reef shell. In doing so, sustainable fishing rates and harvest estimates are generated for both seed and sack oysters. Comparisons of actual annual harvest to simulated annual sustainable harvest reveal years that exceed and years that fall below sustainability targets.

\section{MATERIALS AND METHODS}

\section{Study Area}

The LDWF delineated 7 coastal fisheries management zones across the state, termed coastal study areas (CSAs). In October 2012, the LDWF consolidated CSA 1 with CSA 2, and CSA 4 with CSA5. There are now 5 CSAs in the state. The current study was conducted in CSA 2, located in Breton Sound, a shallow, microtidal estuary in the Mississippi River deltaic plain of southeastern Louisiana (Fig. 1). Coastal study area 2 encompasses about 300,000 of the 880,597 total acres of the Primary Public Oyster Grounds east of the Mississippi River (LDWF 2010).

\section{Stock Assessment}

Since 1988, the LDWF has conducted annual quantitative, fisheries-independent surveys on all state public seed grounds. Divers remove oysters and surficial shell from $1.0-\mathrm{m}^{2}$ grids at designated stations on reefs and shell plants (Fig. 1). Two to 5 grids are sampled at each station. Oysters and boxes (dead oysters with articulated shells) are enumerated, measured, and assigned to $5-\mathrm{mm}$ size classes. The survey therefore provides a quantitative estimate of oyster density with a fine-scale resolution of size (length). Details and findings of the sampling program are published in annual oyster stock assessment reports (e.g., LDWF 2010). In CSA 2, 32 sampling stations are currently established on 30 reefs and 2 shell plants (Fig. 1, Table 1). Throughout the 1999 to 2011 time series used in this study, the number of stations, reefs, and shell plants has changed, as has the acreages associated with reefs and shell plants (Table 1).

\section{Data Management}

Historical records from CSA 21990 to 2010 stock assessments were digitized using an automated data entry form. The digitized data are managed in a database that is queried by the numerical model through a model setup utility.

\section{Model Overview}

Figure 2 shows a schematic of the primary linkages and processes of the sustainable oyster shell stock model. Input from the database includes the length and number of live oysters per square meter at each sample station. User-controlled initialization is provided by the model setup utility. The user chooses the region, year, stations, initial month, mean juvenile natural mortality rate, juvenile natural mortality range, mean adult natural mortality, adult natural mortality range, month of average natural mortality, commercial (sack) fishing fraction and season, seed fishing fraction and season, initial cultch density, shell loss rate, and the von Bertalanffy coefficients $L_{\infty}$ and $k$ for the model run. The utility computes the total area (in square meters) of reefs and shell plants for the year and stations chosen. The model then assigns individuals to $5-\mathrm{mm}$ size classes, tallies the number of oysters in a size class, and designates the number of size classes represented.

Primary model components calculate growth, natural mortality, fishing mortality, cultch density, and sacks of seed and market or sack oysters fished. Oysters that are not lost to natural mortality or removed by fishing grow into new size classes over time. Natural mortality provides new shell to the reef, whereas fishing precludes it. Natural shell loss occurs from taphonomic processes, mostly dissolution and biodegradation. Change in cultch density is thus a function of initial cultch density, recruitment, initial population numbers, size class distribution, shell growth, natural mortality, fishing mortality, and natural shell loss.

The model contains 2 main loops: a monthly loop for simulating time and a size group (size class) loop within. It thus runs for all months in a chosen year and for all size groups for the stations selected (Fig. 2). The number of size groups depends on the year and stations chosen, as established in the initialization phase described earlier. Within the size group loop, sizespecific natural mortality is calculated and the shell equivalent of those oysters is added to the pool of new shell. Oyster growth moves oysters into larger size classes, and the number of oysters removed by fishing is calculated. On exhaustion of the size group loop, shell loss resulting from fishing is determined, and reef cultch density is calculated after adding shell produced by natural mortality and debiting natural shell loss for all months. After the completion of the size group and monthly loops, sacks of seed and market or sack oysters fished, and shell remaining are reported per square meter and as totals for the simulated areas.

Model pseudocode, an informal high-level description of the computer program, is presented in Tables 2 and 3 . The model 


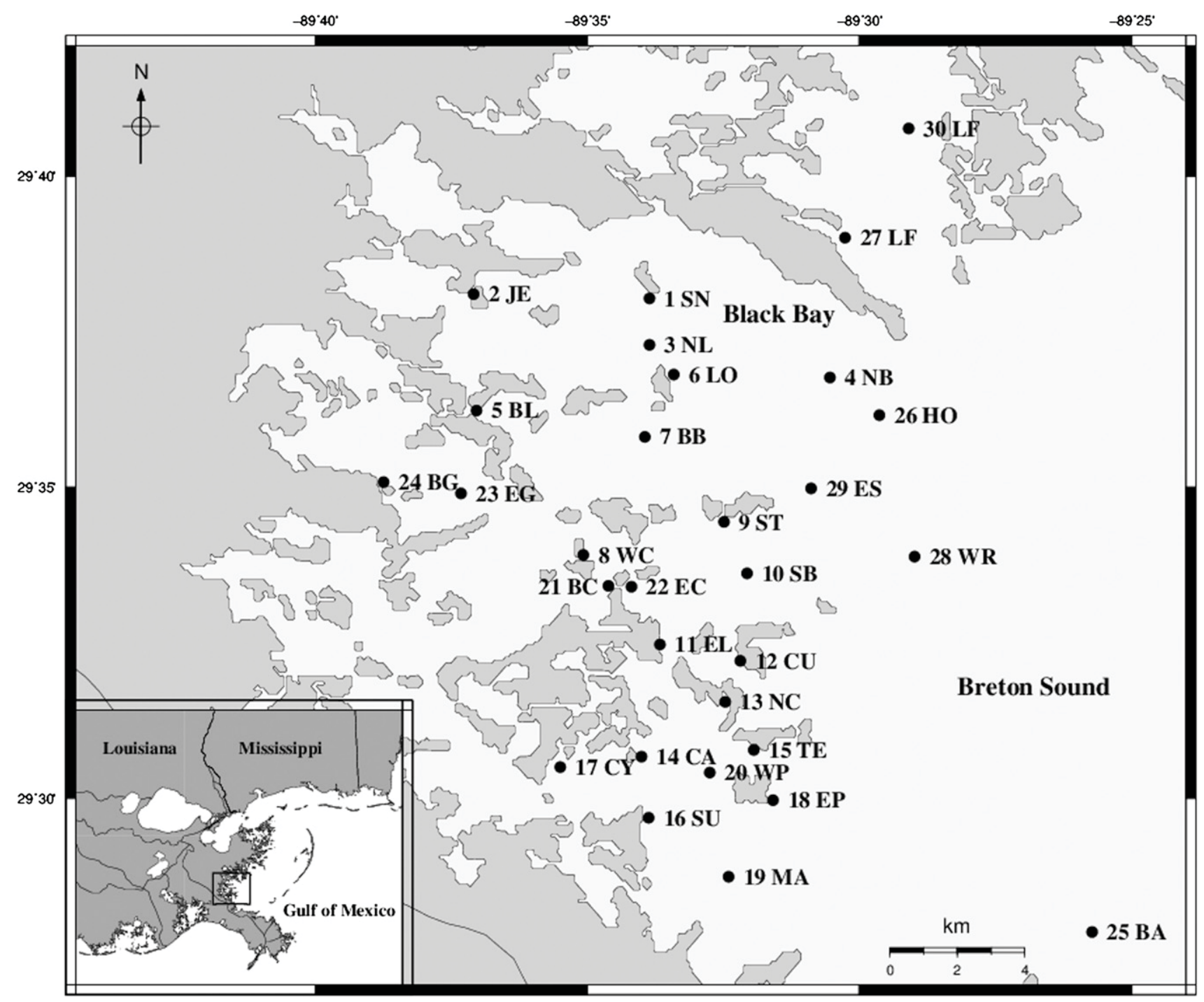

Figure 1. Map of coastal study area 2 sampling stations. Station names corresponding to station abbreviations are given in Table 1.

retrieves data from preloaded databases for a chosen year (y) and a set of chosen stations (S). These values are aggregated (GET_INPUT_RESOURCES, Table 2) to calculate the total region area (region_area) and the total number of oysters in each workgroup $(\mathrm{N})$. These results are sent to the model (GET_NET_SHELL_LOSS, Table 3), which runs the simulation, calculating the net loss of cultch (shell from dead oysters). Iterative loops sum shell loss in each month and for each size group to determine a net annual loss. The simulation is initialized at $t_{0}=7$ (August), the month after the annual stock assessment. Simulations run for 12 mo $\left(t_{\max }=12\right)$. Cultch mass (shell) is initialized as the initial reef shell mass $\left(s_{0}\right)$. At $t_{0}$, harvest of living oysters and dead shell is initialized at 0 . The variables harvest_shell and harvest_oyster track the shell mass fished and oyster sacks fished, respectively, throughout the simulation. Sack oysters, seed oysters, and shell can be fished at different rates $\left(\mathrm{R}_{\text {sack }}, \mathrm{R}_{\text {seed }}, \mathrm{R}_{\text {shell }}\right.$, respectively). Oysters experience natural mortality (MORTALITY_FRACTION), which adds shell to the reef appropriate to their length $(\mathrm{L}[\mathrm{g}])$ and its equivalent mass (OYSTER_MASS, $(\mathrm{L}[\mathrm{g}])$ ). Oysters grow
(NEW_LENGTH) and add shell, but the shell is not credited to the reef until oysters die. Harvest and natural loss $\left(r_{n}\right)$ removes shell mass from the reef. The subroutine returns net loss of shell, number of sacks harvested, and the shell mass harvested.

The equations for growth, natural mortality, fishing mortality, reef shell mass, natural shell loss, and harvest are discussed next.

\section{Growth}

Growth is the change in length $(L)$ over time $(t)$. Length, in turn, is time and age dependent according to a von Bertalanffy growth function:

$$
L(a)=L_{\infty} \times\left[1-e^{-k(t)\left(\frac{a}{12}-a_{0}\right)}\right]
$$

at time $t$, where $L(a)$ is oyster length (in millimeters), which is a function of age $a$ in months (months) and simulation time $t$ in months; and $k(t)$ is a time-dependent von Bertalanffy growth coefficient. Length at infinity, $L_{\infty}$ (measured in millimeters) 
TABLE 1.

Louisiana Department of Wildlife and Fisheries station numbers, names, abbreviations, and areas.

\begin{tabular}{|c|c|c|}
\hline Station number & Station name (abbreviation) & Area (acres) \\
\hline 1 & Snake Island (SN) & 506 \\
\hline 2 & Jessie's Island (JE) & 59 \\
\hline 3 & N. Lonesome Island (NL) & 896 \\
\hline $4^{*}$ & N. Black Bay (NB) & 157 \\
\hline 5 & Bayou Lost (BL) & 118 \\
\hline $6 \dagger$ & Lonesome Island (LO) & 716 \\
\hline 6.1 & 2007 LO Shell Plant (P7) & 200 \\
\hline 6.2 & 2009 LO Shell Plant (P9) & 243 \\
\hline 7 & Black Bay (BB) & 301 \\
\hline 8 & W. Bay Crabe (WC) & 501 \\
\hline 9 & Stone Island (ST) & 461 \\
\hline 10 & S. Black Bay (SB) & 145 \\
\hline 11 & Elephant Pass (EL) & 339 \\
\hline 12 & Curfew (CU) & 425 \\
\hline 13 & N. California Bay (NC) & 109 \\
\hline 14 & California Bay (CA) & 7 \\
\hline 15 & Telegraph (TE) & 127 \\
\hline 16 & Sunrise Point (SU) & 174 \\
\hline $17 \ddagger$ & Bay Long (CY) & 572 \\
\hline 18 & E. Pelican Island (EP) & 782 \\
\hline 19 & Mangrove Point (MA) & 937 \\
\hline 20 & W. Pelican Island (WP) & 293 \\
\hline 21 & Bay Crabe (BC) & 659 \\
\hline 22 & E. Bay Crabe (EC) & 122 \\
\hline 23 & E. Bay Gardene (EG) & 28 \\
\hline 24 & Bay Gardene (BG) & 69 \\
\hline 25 & Battledore Reef (BA) & 1,419 \\
\hline $26^{*}$ & Horseshoe Reef (HO) & 158 \\
\hline $27 \S$ & Lake Fortuna (LF) & 2,144 \\
\hline 28 & Wreck (WR) & 2,276 \\
\hline $29 \|$ & E. Stone Island (ES) & 105 \\
\hline $30 \S$ & Lake Fortuna (LF) & 2,144 \\
\hline
\end{tabular}

* Stations 4 and 26 were combined into 1 station, station 26 ( 315 acres), in year 2001 .

$\dagger$ With a 2007 shell plant (station 6.1), acreage of station 6 was decreased by 200 acres to 516 acres, and with a 2009 shell plant (station 6.2), the acreage of station 6 was decreased by 243 acres to 273 acres. Stock assessment data from station 6.1 were collected in 2008 and 2009, and for station 6.2 in 2011.

+ Station 17 was not sampled in years 1999 to 2008.

$\S$ Stations 27 and 30 were combined into 1 station, station 27 (4,288 acres) in years 1999 to 2006 and 2008.

|| Station 29 was started in 2002 but was not sampled in years 2005 and 2008.

establishes the asymptote of the von Bertalanffy growth curve (Fig. 3). Initial age, $a_{0}$, is age in years when $L=0$. The von Bertalanffy growth coefficient is time dependent according to the equation

$$
k(t)=k_{0}+k_{1} \times \sin \left(2 \pi\left(\frac{t}{12}-t_{0}\right)\right),
$$

where $k(t)$ is the von Bertalanffy growth coefficient as a function of time, $t$ is simulation time (measured in months), $k_{0}$ is the average growth rate, $k_{1}$ is the intra-annual growth rate, and $t_{0}$ is initial time (measured in months) The time dependency of $k$ produces a growth rate that varies seasonally (Fig. 4). The new oyster length, $L_{t+1}$, after a month of growth during month $t$ is calculated as

$$
L_{t+1}(L, t)=L_{\infty} \times\left[1-\left(1-\frac{L}{L_{\infty}}\right) e^{(-k(t) / 12)}\right]
$$

\section{Natural Mortality}

The fraction dying per time unit, $M(t, L)$, is a function of time $t$ (measured in months) and oyster length $L$ (measured in millimeters), expressed as

$$
M(t, L)=1-e^{-m(t, L) / 12} .
$$

The time and length dependency of the natural mortality rate $m$ is

$$
m(t, L)=m_{0}+m_{1} \times \sin \left(2 \pi \times\left(\frac{t-t_{\text {avg }}}{12}\right)\right),
$$

where $m_{0}$ and $m_{1}$ are different for juveniles $(L<25 \mathrm{~mm})$ and adults ( $L \geq 25 \mathrm{~mm}$ ), and $t_{\text {avg }}$ is the time (measured in months) of average mortality. The time dependency of mortality is illustrated in Figure 5. Note that the month during which mortality is average must be stipulated.

\section{Fishing Mortality}

Fishing mortality is assigned as a user option in the initiation stage. Seed and/or sack oysters can be fished simultaneously or independently. The time dependency of fishing is controlled by assigning a value $(0-1.0)$ to the fishing coefficient for the month of interest. The fishing season is, therefore, set up as those months for which the fishing coefficient is greater than 0 . Harvest is determined by the magnitude of the coefficient. For example, a 0.01 value applied to a month for seed oysters means that $1 \%$ of seed oysters are removed in that month.

\section{Reef Cultch Density}

During the initialization phase, an initial cultch density (measured in grams per square meter) for the reef is assigned. Natural mortality adds shell to the reef. Taphonomic processes diminish cultch density. New shell added from natural mortality is calculated as

$$
S(d, L)=d \times s_{A} \times l^{s_{B}}
$$

where $S(d, L)$ is new shell added as a function of $d$; number of dead oysters, $L$, is average oyster length (measured in millimeters); and $s_{A}$ and $s_{B}$ are the allometric coefficients relating shell length to shell mass (Fig. 6).

To determine the shell mass associated with removal by fishing requires knowledge of the number of sacks fished, number of oysters per sack (OPS; Fig. 7), the mean length of the oysters in the sack, and the mass equivalent (measured in grams) of the sack. Oysters per sack as a function of oyster length $(l)$ is

$$
O P S(l)=O P S_{a} \times l^{O P S_{b}}
$$

where $O P S_{a}$ is an oysters-per-sack coefficient and $O P S_{b}$ is an exponent, both derived from the length/number relationship of Hopkins (1950). The sack equivalent $S(g)$ of a given mass of shell (measured in grams) is 


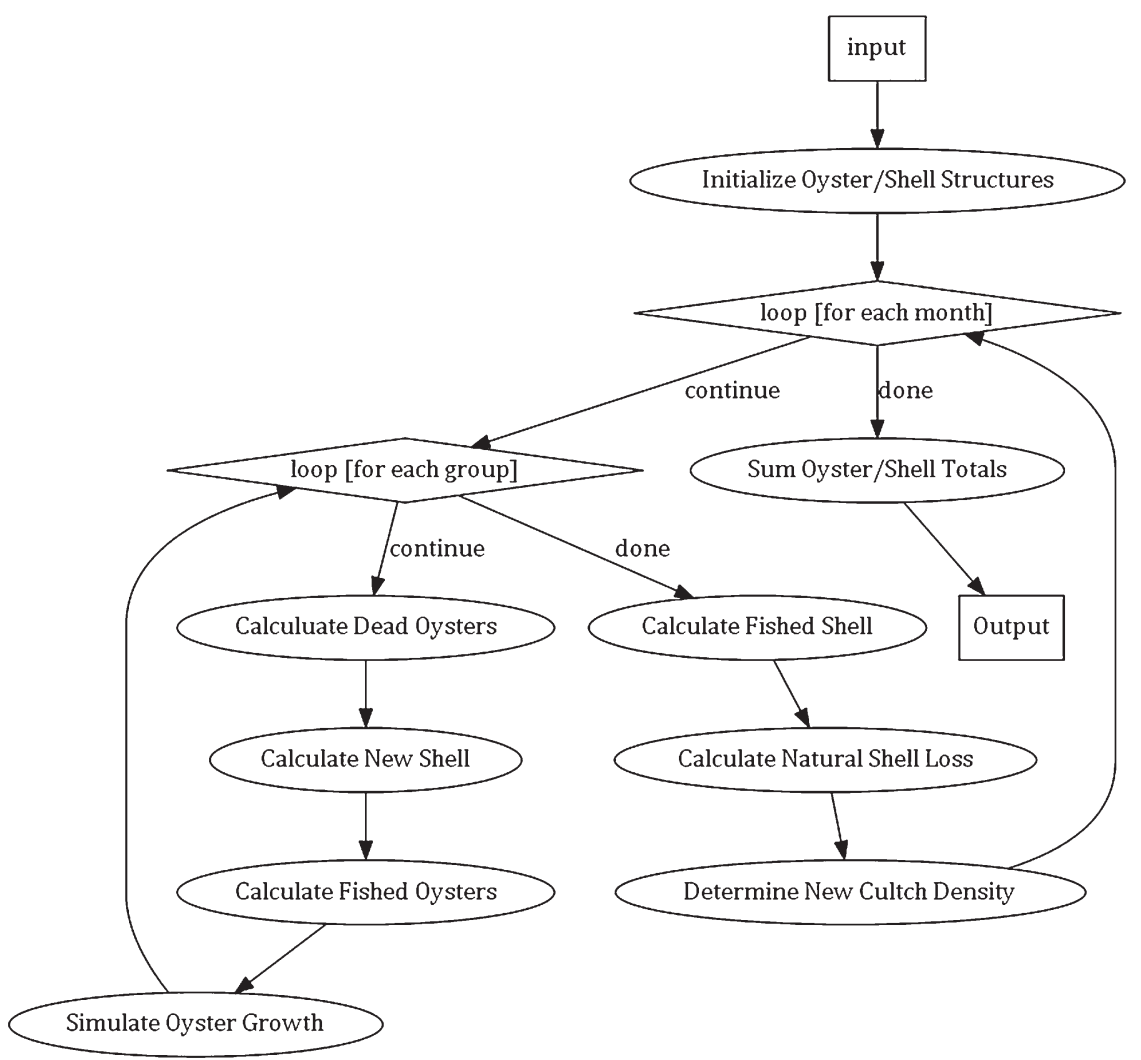

Figure 2. Schematic of major oyster model processes.

$$
S(g)=\frac{g}{D \times C \times P}
$$

where $g$ is shell mass (measured in grams), $D$ is shell density (measured in grams per liter), $C$ is sack capacity ( $52.85 \mathrm{~L} /$ sack), and $P$ is a packing coefficient, or the ratio of shell volume to expanded cultch volume.

\section{Natural Shell Loss}

Loss of surficial shell diminishes the function of the substrate to attract larvae and support newly settled ones. Natural shell loss is operationally defined as the diminution in shell mass resulting from dissolution (Waldbusser et al. 2011), biodegradation, and the export of small pieces of shell off the reef, loss of clean shell surface area resulting from burial below the oxidized layer, and fragmentation into small pieces, which are easily roiled and thus prevent settlement or survival of larvae (MacKenzie 1977, Gunter 1979). Shell loss $S_{L, t}$ (measured in grams) for a given month $t$ is initialized as a monthly percent shell loss. Shell losses are subtracted and shell gains are added to the amount of current shell $S_{t}$ (measured in grams) in a month $t$ to determine reef cultch density for the next month $\left(S_{(t+1)}\right)$ such that

$$
S_{t+1}=S_{t}-S_{F, t}-S_{L, t}+S_{N, t}
$$

where $S_{F, t}$ is shell removed as part of the fishing process in the current month and $S_{N, t}$ is new shell added in the current month from natural mortality. Fishing removal of shell in this case is associated primarily with seed removal, because much of the seed is attached to shell and not to live oysters. Note that cultch density in $\mathrm{Eq}$ (11) does not include the mass of live oysters, which is treated separately.

\section{Harvest and Fishing}

Number of commercial (sack) oysters harvested $\left(H_{C}\right)$ is expressed as

$$
H_{C}=\left(C_{F, C} \times N_{C}\right)
$$

where $C_{F, C}$ is the fraction of commercial-size oysters harvested and $N_{C}$ is the number of oysters in the commercial size group. Likewise, the number of seed harvested $\left(H_{S}\right)$ is

$$
H_{S}=\left(C_{F, S} \times N_{S}\right)
$$

where $C_{F, S}$ is the fraction of seed size oysters harvested and $N_{S}$ is the number of oysters in the seed size group. Harvest is reported in sacks by dividing the number of oysters fished in each size group $\left(f_{i}\right)$ by the size-appropriate number of oysters per sack and summing across all size groups where

$$
\text { Sacks Harvested }=\sum_{i=1}^{n}\left(\frac{f_{i}}{\operatorname{OPS}\left(l_{i}\right)}\right)
$$

\section{Fishing Scenarios}

As mentioned earlier, the time dependency of fishing and fishing effort is controlled by assigning a value $(0-1.0)$ to the 
TABLE 2.

GET_INPUT_RESOURCES pseudocode.

\begin{tabular}{|c|c|c|}
\hline Symbol & Description & Example \\
\hline $\mathrm{y}$ & The sample year & (parameter) \\
\hline S & The set of stations from which to sample & (parameter) \\
\hline $\mathrm{D}$ & $\begin{array}{l}\text { Database loaded with YEAR } \times \text { STATION } \times \\
\text { SAMPLE } \times \text { GROUP data }\end{array}$ & (database) \\
\hline A & Database loaded with STATION acreages. & (database) \\
\hline $\begin{array}{l}\text { GET_II } \\
\text { var re } \\
\text { var N } \\
\text { var T } \\
\text { for ea }\end{array}$ & $\begin{array}{l}\text { PUT_RESOURCES }(\mathrm{y}, \mathrm{S}) \\
\text { ion_area } \leftarrow 0 \\
\leftarrow \text { a new array; } \\
\leftarrow \text { a new array; } \\
\text { h station s in } \mathrm{S}\end{array}$ & \\
\hline $\begin{array}{r}\text { reg } \\
\text { for } \\
\mathrm{f} \\
\text { for }\end{array}$ & $\begin{array}{l}\text { n_area } \leftarrow \text { region_area }+\mathrm{A}[\mathrm{s}] \\
\mathrm{ach} \text { ample } \mathrm{n} \text { in } \mathrm{D}[\mathrm{y}][\mathrm{s}] \\
\mathrm{r} \text { each group } \mathrm{g} \text { in } \mathrm{D}[\mathrm{y}][\mathrm{s}][\mathrm{n}] \\
\mathrm{T}[\mathrm{s}][\mathrm{g}] \leftarrow \mathrm{T}[\mathrm{s}][\mathrm{g}]+\mathrm{D}[\mathrm{y}][\mathrm{s}][\mathrm{n}][\mathrm{g}] \\
\text { ach group g from } 1-40\end{array}$ & \\
\hline \multicolumn{3}{|c|}{$\mathrm{N}[\mathrm{g}] \leftarrow \mathrm{N}[\mathrm{g}]+\frac{\mathrm{T}[\mathrm{s}][\mathrm{g}]}{|\mathrm{D}[\mathrm{y}][\mathrm{s}]|} \times \mathrm{A}[\mathrm{s}]$} \\
\hline $\begin{array}{l}\} \\
\text { retur1 }\end{array}$ & $(\mathrm{N}$, region_area); & \\
\hline
\end{tabular}

fishing fraction coefficient $\left(C_{F}\right)$ for the month of interest. However, different fishing modes result in differential incidental harvest of dead shell and live oysters. Fishing for shell, seed, and sack-size (commercial) oysters are separated explicitly in the model, allowing for the evaluation of the impact of various fishing scenarios. Three common fishing scenarios are (1) direct harvest of sack oysters, (2) fishing for seed on public grounds and planting them on private leases, and (3) wholesale planting of sack oysters, seed, and shell from public grounds to private leases. Direct harvest is selected fishing for sack oysters that are culled, sacked, and marketed immediately. Direct harvest (sacking) includes an incidental harvest of seed and shell, but for the sake of simplicity this removal is assumed to be de minimis and is not included in the simulations presented herein. Fishing for seed imposes a shell fishing rate equivalent to the seed fishing rate because the shell on which the seed is attached is not culled easily or routinely, whereas wholesale planting removes (at an equal rate) sack oysters, seed, and shell from the public grounds to private leases. Thus, various fishing scenarios result in differential impacts on the shell budget. In the current simulations, sack and seed oysters are fished simultaneously. Fishing effort (fishing fraction) is manipulated to achieve the sustainability criterion of no net loss of reef shell.

\section{RESULTS}

Table 4 shows the status of the initial stock, fishing effort for seed and sack oysters, and model outputs for simulations for 1999 to 2011 . Shell density is initialized at $5,000 \mathrm{~g} / \mathrm{m}^{2}$ for all simulations. The number of oysters on the seed grounds varied from $2.95 \times 10^{9}$ to in 2000 to $3.89 \times 10^{7}$ in 2011 . Likewise, oyster density showed a similar trend during the same period with a high of 45.4 oysters $/ \mathrm{m}^{2}$ in 2000 and a low of 0.58 oysters $/ \mathrm{m}^{2}$ in 2011. Oyster mass (the shell mass of living oysters) peaked
TABLE 3.

GET_NET_SHELL_LOSS pseudocode.

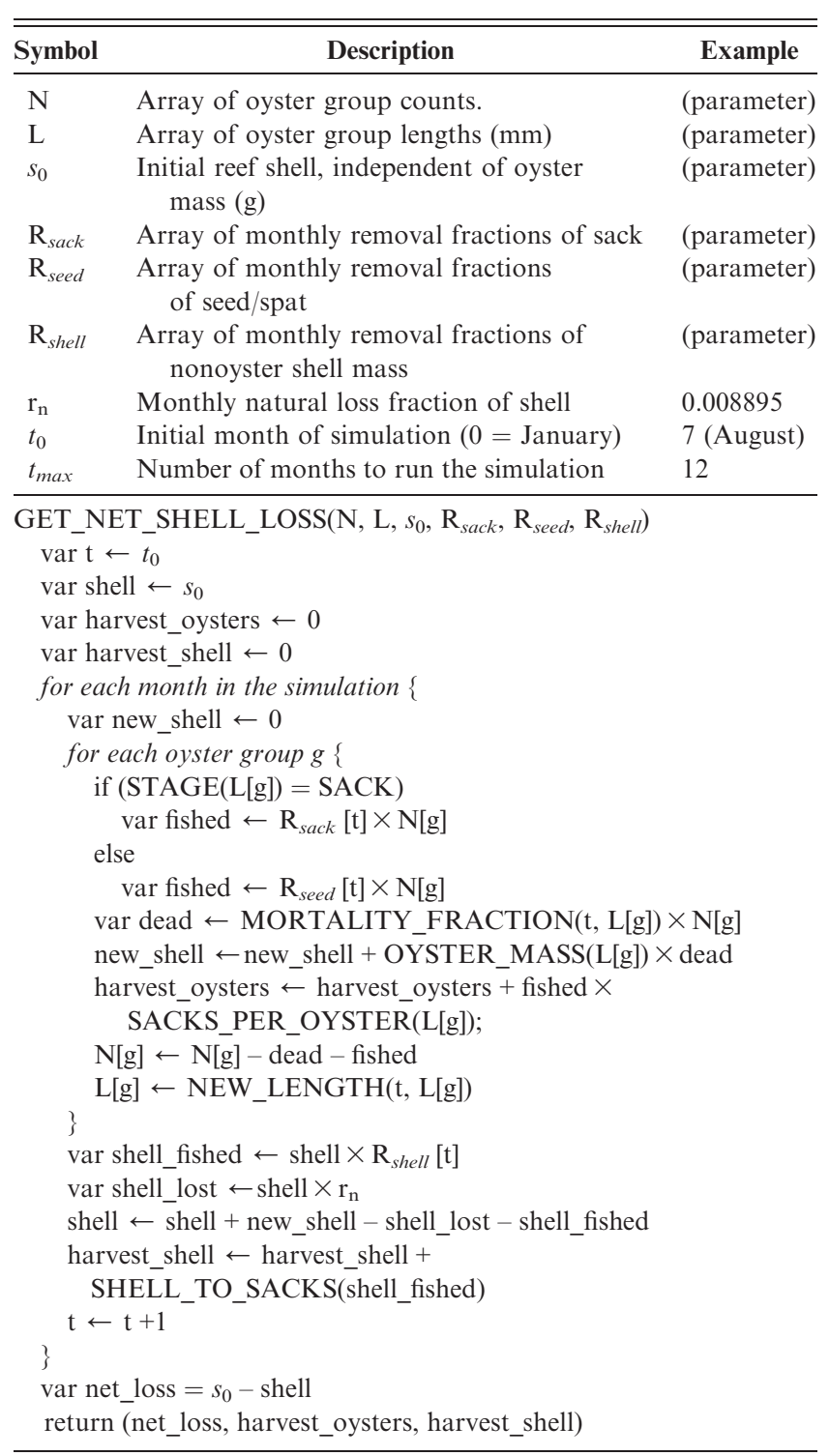

at $2,519 \mathrm{~g} / \mathrm{m}^{2}$ in 2001 and was lowest in 2010 at $53 \mathrm{~g} / \mathrm{m}^{2}$. Mean oyster length varied from $76.9 \mathrm{~mm}$ in 2011 to $22.5 \mathrm{~mm}$ in 2009. Sustainable sack fishing effort ranged from $0.25 / \mathrm{mo}$ in 2000 to $0 / \mathrm{mo}$ in 2008,2010 , and 2011 , whereas seed/shell

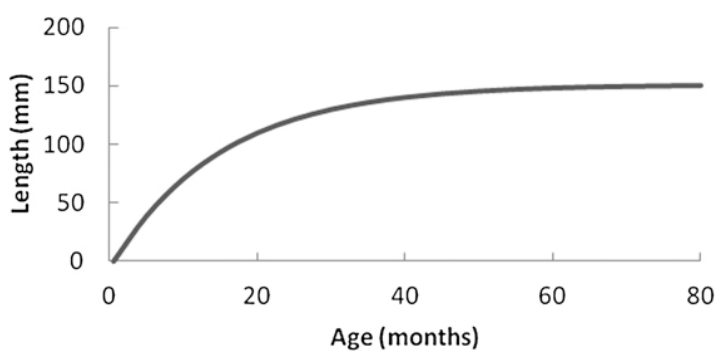

Figure 3. Oyster length as a function of age. Length at infinity, $L_{\infty}=$ $151 \mathrm{~mm}$. 


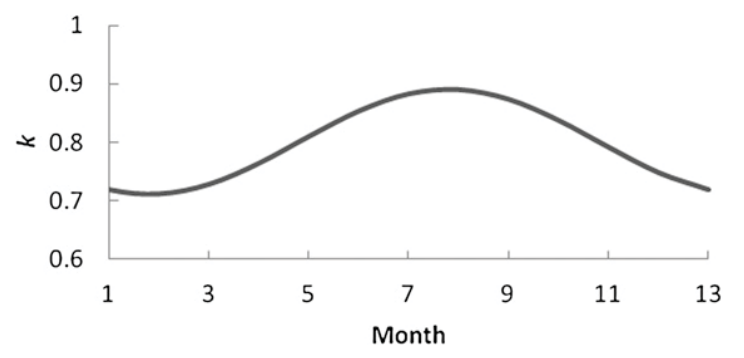

Figure 4. Time dependency of the von Bertalanffy growth coefficient, $k$.

fishing effort ranged from $0.02 / \mathrm{mo}$ in 2000 to $0 / \mathrm{mo}$ in 2005 , 2008, 2010, and 2011. Average sack fishing rate for the 7-mo season over the time series was $0.102 /$ mo versus a seed/shell fishing rate of $0.007 / \mathrm{mo}$. In the simulations, the volume of shell fished varied from 661,000 sacks in 2000 to 0 sacks in 2005, 2008, 2010, and 2011, the years that no seed was fished. An attempt was made to fish at a rate such that there was no diminution of shell density (shell of dead oysters) and, because the shells of live oysters do not accrete to the reef until oysters die, no diminution of reef mass. It was not always possible to achieve an exact balance between these conditions. Emphasis was, therefore, placed on achieving no reef mass loss $( \pm 5 \%)$. In 2010 and 2011, however, when no fishing was simulated, reef mass losses exceeded $5 \%$. Final shell density varied from $5,357 \mathrm{~g} / \mathrm{m}^{2}$ in 2001 to $4,372 \mathrm{~g} / \mathrm{m}^{2}$ in 2006 . Percent shell loss varied from $-7.1 \%$ in 2001 (a gain of $7 \%$ ) to $12.6 \%$ in 2006 . Oysters dead is the percent of oysters that died over simulated time; it varied from $46.6 \%$ in 2009 to $33.6 \%$ in 2001 . Final oyster mass ranged from $2,336 \mathrm{~g} / \mathrm{m}^{2}$ in 2001 to $101 \mathrm{~g} / \mathrm{m}^{2}$ in 2011. Oyster mass as a percent change between initial and final mass ranged from $378 \%$ in 2009 to $93 \%$ in 2001. Final oyster density was greatest in $2000\left(10.3\right.$ oysters $\left./ \mathrm{m}^{2}\right)$ and lowest in $2011\left(0.34\right.$ oysters $\left./ \mathrm{m}^{2}\right)$. The highest simulated sustainable seed harvest was 816,000 sacks (year 2000); in 2005, 2008, 2010, and 2011, no amount of seed harvest was deemed sustainable. In 2001, a high of 3,066,000 sacks of sack oysters was calculated to be a sustainable harvest, whereas in some years $(2008,2010$, and 2011) no amount of fishing was considered sustainable.

Table 5 provides LDWF stock assessment and harvests estimates for sack and seed oysters; harvest as a percent of available stock for sack and seed oysters is calculated. Simulated sustainable estimates of sack and seed oysters are presented, and harvest as a percent of simulated harvest for sack and seed oyster are given. Stock estimates of sack oysters range

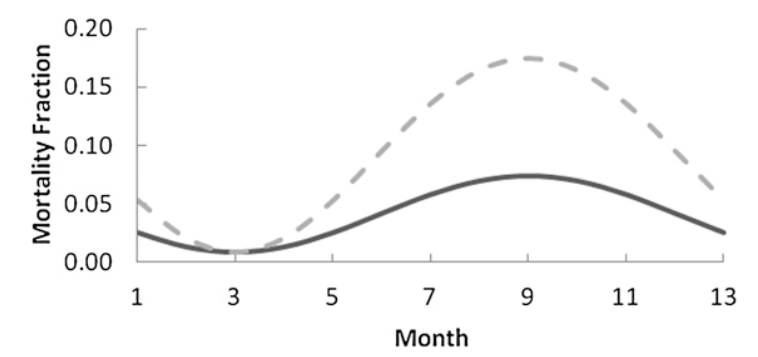

Figure 5. Time dependency of monthly natural mortality fraction. Dashed line, juveniles $(L<25 \mathrm{~mm})$; solid line, adults $(L \geq 25 \mathrm{~mm})$.

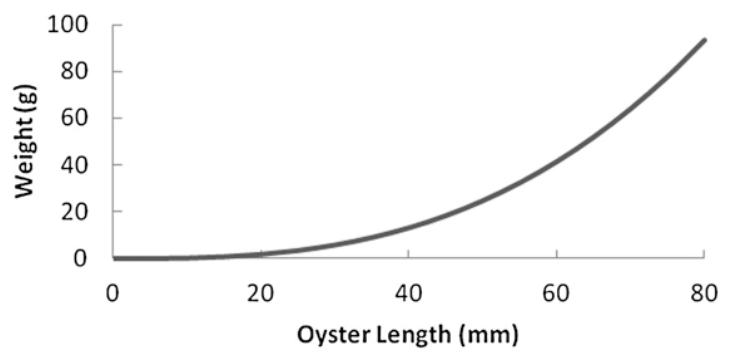

Figure 6. Conversion of oyster length to oyster shell weight. from 4,642,996 sacks in 2001 to 156,900 sacks in 2009; stock seed estimates show a 2000 high of $6,828,812$ sacks and a 2008 low of 221,502 sacks. Harvest of sack oysters was greatest in 2001 (844,898 sacks) and lowest in 2009 (167,614 sacks). Seed harvest varied from 626,320 in 2003 to 58,270 in 2005. In 2008 and 2009, all the stock of sack oysters was harvested. (Values greater than $100 \%$ suggest errors in the estimate of stock abundance and/or harvest.) In contrast, only $18.2 \%$ of the stock of sack oysters was harvested in 2001. In 2008, $69.5 \%$ of available seed was harvested, whereas in 2000 only $3.0 \%$ was taken. Sustainable estimates for allowable catch of sack oysters varied from 3,065,531 (2001) to 0 sacks (2008). No fishing of sack oysters was considered sustainable in 2008 , yet 265,581 sacks were harvested; in 2005 harvest also exceeded sustainability estimates. In year 2000 , only $13.2 \%$ of the sustainable sack estimate was harvested. In most years (2002 to 2005, 2007, 2008), the harvest of seed oysters exceeded sustainable harvest estimates. In 2005 and 2008, no harvest of seed was considered sustainable, yet 58,270 sacks were harvested in 2005 and 154,006 sacks were harvested in 2008. In contrast, in the 2000 oyster season, only 201,560 sacks of seed (24.7\%) of the simulated sustainable catch of 816,468 sacks were harvested.

\section{DISCUSSION}

Sustainable fishing rates for seed oysters appear to be about an order of magnitude less than sustainable fishing rates for sack oysters. In most years the harvest of seed was not sustainable, whereas sustainability goals were often achieved for sack oysters. A notable exception was 2000, a year of abundant seed oysters in which less than $25 \%$ of the sustainability goal for seed oysters was harvested. For both seed and sack oysters the general trend in the simulated time series is from sustainable harvests in the early years of abundance to unsustainable harvests in the recent years of paucity. In some years toward

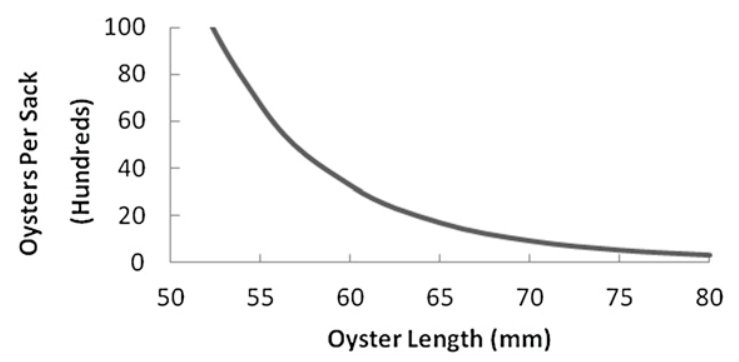

Figure 7. Number (hundreds) of oysters per sack for oysters of various length. 
TABLE 5.

Stock assessment and harvest estimates from the Louisiana Department of Wildlife and Fisheries, and harvest as a percent of the available stock for sack and seed oysters.

\begin{tabular}{|c|c|c|c|c|c|c|c|c|c|c|}
\hline Year & $\begin{array}{c}\text { Stock } \\
\text { sack } \\
\text { (sacks) }\end{array}$ & $\begin{array}{c}\text { Stock } \\
\text { seed } \\
\text { (sacks) }\end{array}$ & $\begin{array}{c}\text { Harvest } \\
\text { sack } \\
\text { (sacks) }\end{array}$ & $\begin{array}{c}\text { Harvest } \\
\text { seed } \\
\text { (sacks) }\end{array}$ & $\begin{array}{c}\% \\
\text { Harvest/stock } \\
\text { (sack) }\end{array}$ & $\begin{array}{c}\% \\
\text { Harvest/stock } \\
\text { (seed) }\end{array}$ & $\begin{array}{c}\text { Sim. sack } \\
\text { fished (sacks) }\end{array}$ & $\begin{array}{c}\text { Sim. seed } \\
\text { fished (sacks) }\end{array}$ & $\begin{array}{c}\% \\
\text { Harvest/Sim. } \\
\text { (sack) }\end{array}$ & $\begin{array}{c}\% \\
\text { Harvest/Sim. } \\
\text { (seed) }\end{array}$ \\
\hline 1999 & $1,989,508$ & $3,382,040$ & 700,617 & 138,056 & 35.2 & 4.1 & $2,012,018$ & 372,441 & 34.8 & 37.1 \\
\hline 2000 & $1,754,696$ & $6,828,812$ & 403,374 & 201,560 & 23.0 & 3.0 & $3,049,175$ & 816,468 & 13.2 & 24.7 \\
\hline 2001 & $4,642,996$ & $3,851,418$ & 844,898 & 318,490 & 18.2 & 8.3 & $3,065,531$ & 385,332 & 27.6 & 82.7 \\
\hline 2002 & $1,937,488$ & $1,201,982$ & 704,284 & 281,766 & 36.4 & 23.4 & $1,004,700$ & 176,001 & 70.1 & 160.1 \\
\hline 2003 & $1,134,036$ & $1,598,908$ & 286,963 & 626,320 & 25.3 & 39.2 & 751,139 & 87,736 & 38.2 & 713.9 \\
\hline 2004 & 741,188 & $1,497,112$ & 535,936 & 391,072 & 72.3 & 26.1 & 634,174 & 86,670 & 84.5 & 451.2 \\
\hline 2005 & 598,628 & 778,146 & 271,271 & 58,270 & 45.3 & 7.5 & 234,559 & 0 & 115.7 & $*$ \\
\hline 2006 & 308,986 & $2,215,294$ & 183,355 & 221,134 & 59.3 & 10.0 & 794,925 & 536,576 & 23.1 & 41.3 \\
\hline 2007 & 619,124 & 902,068 & 278,580 & 347,170 & 45.0 & 38.5 & 414,042 & 340,485 & 67.3 & 102.0 \\
\hline 2008 & 248,786 & 221,502 & 265,581 & 154,006 & 106.8 & 69.5 & 0 & 0 & $*$ & $*$ \\
\hline 2009 & 156,900 & 483,524 & 167,614 & 165,376 & 106.8 & 34.2 & 476,887 & 354,295 & 35.1 & 46.7 \\
\hline
\end{tabular}

* Results for which a division by 0 would occur, indicating harvest greatly exceeds simulation estimate.

Sustainable catch from the model simulation and harvest as a percent of the sustainable catch for sack and seed oysters. Data from the Louisiana Department of Wildlife and Fisheries for 2010 and 2011 have not been released. Sim., simulation.

the end of the time series, no level of fishing was considered sustainable. That is, insufficient oysters were present at the beginning of the season to support the deaths needed to offset the loss of shell resulting from natural processes (Powell et al. 2006, Powell \& Klinck 2007, Waldbusser et al. 2011).

As argued by Powell et al. (2009a, 2009b), extreme annual variation in oyster stocks precludes the application of standard biological reference points such as carrying capacity. Good years often follow good years and bad years often follow bad years, punctuated by regime shifts (Powell et al. 2008). Oyster reefs exhibit a system memory provided through the persistence (or loss) of cultch, the shell mass associated with living oysters, and the number of surviving oysters that constitute the spawning stock. Sustainable harvest of oysters in Louisiana, and likely elsewhere, as indicated by application of this shell-neutral model, is an annual moving target that precludes the application of standard production and maximum sustained yield models.

The assumption of an initial cultch density made it possible to determine sustainable harvests in the absence of measured cultch densities; however, sustainable fishing rates and associated harvest allotments are dependent, in part, on the assumption of the initial cultch mass. With a high initial cultch mass, more natural shell loss occurs, and to compensate, more oysters must remain on the reef and die there. In the simulations, it was assumed that the reef was in good condition (initial cultch = $5000 \mathrm{~g} \mathrm{~m}^{-2}$; Mann et al. 2009), and harvest was not diminished to build reef (i.e., for a shell gain). The modeling exercise clearly demonstrates the need to monitor cultch density and adopt a reference point that constitutes adequate cultch. A measured value for initial cultch density would then establish reef condition, and fishing could be adjusted to achieve the reference point goal at the end of the season. The measurement of cultch density the following stock assessment would indicate if the cultch reference goal was achieved.

The model permits area management by grouping stations with similar attributes and treating them as a functional unit. Attributes of particular importance are oyster growth and mortality, especially because they vary across the salinity gradient. However, in the simulations described herein, a single value each month for growth and mortality across all years and stations was used. Further model refinement would involve empirically based parameterization of the growth and mortality equations. Regional environmental and climatic variability have been shown to alter oyster growth and mortality ratesdramatically (La Peyre et al. 2009, Soniat et al. 2009), and experimental work has demonstrated that growth and mortality may vary substantially between years, across stations, and by size class (La Peyre et al. 2003, La Peyre et al. 2009, Eberline 2012). For example, in a recent 2-year study in Breton Sound, growth ranged from a mean monthly rate as low as $0.2 \mathrm{~mm} / \mathrm{mo}$ to as high as $7.9 \mathrm{~mm} / \mathrm{mo}$ across stations, years, and size classes (Eberline 2012). These differences are suggested to be related to the local salinity regime, which may be influenced by regional climatic patterns and local water management (Klinck et al. 2002, Powell et al. 2003, Wang et al. 2008, La Peyre et al. 2009). Refining the growth and mortality equations to account for this level of variation should improve model predictions significantly.

The no-net-shell-loss approach to sustainability is broadly applicable to the eastern oyster, a quintessentially r-selected species that also builds the substrate on which its future generations depend. The population dynamics of Crassostrea virginica in the Gulf of Mexico have many r-selected attributes, even though the species is iteroparous. Growth rates and mortality rates are high, life span is often limited to 1-2 years, and 2 generations per year are often possible. In more northern climes, $C$. virginica population dynamics take on more of the bethedging lifestyle, and iteroparity and long life become increasingly important components of species persistence. Although applied initially to the Louisiana fishery, with local parameterization the model should prove useful in estimating sustainable harvests and in evaluating the success of reef restoration of the eastern oyster across its entire range. Oyster fisheries that remove shell versus reef restorations that promote shell accretion, although divergent in their goals, are convergent in their management; both require vigilant attention to shell budgets. 


\section{ACKNOWLEDGMENTS}

This work was funded by Louisiana Sea Grant (grant no. R/AOS-02) and the LDWF (contract no. CFMS70259757).
Keith B. Ibos, Brian Lezina, and Patrick Banks of the LDWF provided access to and assistance with annual stock assessment data. Thoughtful reviews of an early draft of the manuscript were provided by Gregg Snedden, Keith Ibos, and Patrick Banks.

\section{LITERATURE CITED}

Butler, P. A. 1953. Oyster growth as affected by latitudinal temperature gradients. Commer. Fish. Rev. 15:7-12.

Chatry, M., R. J. Dugas \& K. A. Easley. 1983. Optimum salinity regime for oyster production on Louisiana's state seed grounds. Contrib. Mar. Sci. 26:81-94.

Choi, K.- S., E. N. Powell, D. H. Lewis \& S. M. Ray. 1994 Instantaneous reproductive effort in female American oysters, Crassostrea virginica, measured by a new immunoprecipitation assay. Biol. Bull. 186:41-61.

Dugas, R. J., E. A. Joyce \& M. E. Berrigan. 1997. History and status of the oyster, Crassostrea virginica, and other molluscan fisheries of the U.S. Gulf of Mexico. In: C. L. Mackenzie, Jr., V. G. Burrell, Jr., A. Rosenfield \& W. L. Hobart, editors. The mollusk fisheries of North and Central America and Europe. National Marine Fisheries Service. U.S. Department of Commerce, NOAA technical report. Seattle, WA. pp. 187-210.

Eberline, B. S. 2012. Population dynamics of the eastern oyster in the northern Gulf of Mexico. MS thesis, Louisiana State University. $62 \mathrm{pp}$.

Gunter, G. 1979. The grit principle and the morphology of oyster reefs. Proc. Natl. Shellfish. Assoc. 69:1-5.

Hayes, P. F. \& R. W. Menzel. 1981. The reproductive cycle of early setting Crassostrea virginica (Gmelin) in the northern Gulf of Mexico, and its implications for population recruitment. Biol. Bull. 160:80-88.

Hopkins, S. H. 1950. The inter-relationship of weight, volume, and linear measurements of oysters and the number of oysters per Louisiana sack. Texas A\&M Research Foundation report, project 9. College Station, TX: Texas A\&M Research Foundation. $14 \mathrm{pp}$.

Hopkins, S. H. 1954. Oyster setting on the Gulf coast. Proc. Natl. Shellfish. Assoc. 45:52-55.

Ingle, R. M. \& C. E. Dawson, Jr. 1952. Growth of the American oyster, Crassostrea virginica (Gmelin) in Florida waters. Bull. Mar. Sci. Gulf Caribb. 2:393-403.

Klinck, J. M., E. N. Powell, J. N. Kraeuter, S. E. Ford \& K. A. Ashton-Alcox. 2001. A fisheries model for managing the oyster fishery during times of disease. J. Shellfish Res. 20:977-989.

Klinck, J. M., E. E. Hofmann, E. N. Powell \& M. M. Dekshenieks. 2002. Impact of channelization on oyster production: a hydrodynamicoyster population model for Galveston Bay, Texas. Environ. Model. Assess. 7: 273-289.

La Peyre, M. K., A. D. Nickens, A. K. Volety, G. S. Tolley \& J. F. La Peyre. 2003. Environmental significance of freshets in reducing Perkinsus marinus infection in eastern oysters Crassostrea virginica: potential management applications. Mar. Ecol.-Prog. Ser. 248: 165176.

La Peyre, M. K., B. Gossman \& J. F. La Peyre. 2009. Defining optimal freshwater flow for oyster production: effects of freshet rate and magnitude of change and duration on Eastern oysters and Perkinsus marinus infection. Estuaries Coasts 32:522-534.
LDWF. 2010. Oyster stock assessment of the public oyster areas in Louisiana. Baton Rouge, LA: Louisiana Department of Wildlife and Fisheries. 86 pp.

MacKenzie, C. L., Jr. 1977. Development of an aquacultural program for rehabilitation of damaged oyster reefs in Mississippi. Mar. Fish. Rev. 45:1-22.

Mann, R. \& E. N. Powell. 2007. Why oyster restoration goals in the Chesapeake Bay are not and probably cannot be achieved. J. Shellfish Res. 26:905-917.

Mann, R., M. Southworth, J. M. Harding \& J. A. Wesson. 2009. Population studies of the native Eastern oyster, Crassostrea virginica, (Gmelin, 1791) in the James River, Virginia, USA. J. Shellfish Res. 28:193-220.

Melancon, E., T. Soniat, V. Cheramie, R. Dugas, J. Barras \& M. Lagarde. 1998. Oyster resource zones of the Barataria and Terrebonne estuaries of Louisiana. J. Shellfish Res. 17:1143-1148.

Powell, E. N., K. A. Ashton-Alcox, J. N. Kraeuter, S. E. Ford \& D. Bushek. 2008. Long-term trends in oyster population dynamics in Delaware Bay: regime shifts and response to disease. J. Shellfish Res. 27:729-755.

Powell, E. N. \& J. M. Klinck. 2007. Is oyster shell a sustainable estuarine resource? J. Shellfish Res. 26:181-194.

Powell, E. N., J. M. Klinck, K. Ashton-Alcox, E. E. Hofmann \& J. Morson. 2012. The rise and fall of Crassostrea virginica oyster reefs: the role of disease and fishing in their demise and a vignette on their management. J. Mar. Res. 70:505-558.

Powell, E. N., J. M. Klinck, K. A. Ashton-Alcox \& J. N. Kraeuter. 2009a. Multiple stable reference points in oyster populations: biological relationships for the Eastern oyster (Crassostrea virginica) in Delaware Bay. Fish Bull. 107:109-132.

Powell, E. N., J. M. Klinck, K. A. Ashton-Alcox \& J. N. Kraeuter. 2009b. Multiple stable reference points in oyster populations: implications for reference point-based management. Fish Bull. 107:133-147.

Powell, E. N., J. M. Klinck, E. E. Hofmann \& M. A. McManus. 2003. Influence of water allocation and freshwater inflow on oyster production: a hydrodynamic-oyster population model for Galveston Bay, Texas, USA. Environ. Manage. 31:100-121.

Powell, E. N., J. N. Kraeuter \& K. A. Ashton-Alcox. 2006. How long does oyster shell last on an oyster reef? Estuar. Coast. Shelf Sci. 69:531-542.

Soniat, T. M., E. E. Hofmann, J. M. Klinck \& E. N. Powell. 2009. Differential modulation of Eastern oyster (Crassostrea virginica) disease parasites by El Nino-Southern Oscillation and the North Atlantic Oscillation. Int. J. Earth Sci. 98:99-114.

Waldbusser, G. G., R. A. Steenson \& M. A. Green. 2011. Oyster shell dissolution rates in estuarine waters: effects of $\mathrm{pH}$ and shell legacy. J. Shellfish Res. 30:659-669.

Wang, H., W. Huang, M. A. Harwell, L. Edmiston, E. Johnson, P. Hsieh, K. Milla, K. Christensen, J. Stewart \& X. Liu. 2008. Modeling oyster growth rate by coupling oyster population and hydrodynamic models for Apalachicola Bay, Florida, USA. Ecol. Modell. 211:77-89. 